\title{
Unexpected different chemoselectivity in the aerobic oxidation of methylated planar catechin and bent epicatechin derivatives catalysed by the Trametes villosa laccase/1-hydroxybenzotriazole system $\dagger$
}

\author{
Roberta Bernini, ${ }^{\text {*a }}$ Fernanda Crisante, ${ }^{a}$ Patrizia Gentili, ${ }^{* b}$ Sergio Menta, ${ }^{c}$ \\ Fabio Morana ${ }^{b}$ and Marco Pierini ${ }^{c}$
}

\begin{abstract}
Unreported methylated catechin and epicatechin derivatives 5 and 6 were synthesized by an oxa-PictetSpengler reaction. Catechin 5 shows the $B$ and $C$ rings coplanar because of the formation of a trans junction between the $C$ ring and the newly generated six-term cycle $D$, in turn condensed to ring $B$. In contrast, epicatechin 6 presents a bent geometry due to the establishment of a cis junction between the $C$ ring and the newly formed cycle D. The oxidation of compounds 5 and 6 in the presence of the Trametes villosa laccase/1-hydroxybenzotriazole (HBT) system was investigated under aerobic conditions in both a biphasic system and a reverse micelle. The unexpected different chemoselective oxidation at the benzylic position of catechin and epicatechin derivatives 5 and 6 has been rationalized using a molecular modelling approach. These results demonstrate that the Trametes villosa laccase/HBT system represents a useful tool to functionalize the C-2 or C-4 position of phenolic compounds depending on the structural features.
\end{abstract}

Received 5th August 2013

Accepted 6th January 2014

DOI: $10.1039 / c 3 r a 47753 c$

www.rsc.org/advances
Being biodegradable and able to perform oxidations under mild experimental conditions, their use presents several advantages. Laccases can catalyse the monoelectronic oxidation of both organic compounds $s^{3}$ and inorganic ions ${ }^{4}$ with the simultaneous reduction of molecular dioxygen to water without the intermediate production of hydrogen peroxide. Laccases' potential use in oxidation reactions can be increased by combination with low molecular weight compounds termed mediators. These compounds enable these enzymes to oxidize substrates with a redox potential above $1.3 \mathrm{~V}(e . g$. benzylic alcohols and ethers) by means of an indirect way where the active species is the oxidized form of the mediator. ${ }^{5}$

Mediators can act as an "electron shuttle": once oxidized by laccases and converted to more or less stable radicals, they diffuse far away from the enzymatic pocket and, by mechanisms different from the enzymatic one, enable the oxidation of target compounds that in principle are not substrates of laccases because of their large size or high redox potential (Scheme 1). ${ }^{6}$

Dipartimento di Scienze e Tecnologie per l'Agricoltura, le Foreste, la Natura l'Energia (DAFNE), Università degli Studi della Tuscia, Via S. Camillo De Lellis, 01100 Viterbo, Italy. E-mail: berninir@unitus.it; Fax: +39 0761 357242; Tel: +39 0761357452

${ }^{b}$ Dipartimento di Chimica and IMC-CNR Sezione Meccanismi di Reazione, Università degli Studi La Sapienza, P. le A. Moro 5, 00185 Roma, Italy.E-mail: patrizia.gentili@ uniroma1.it; Fax: +3906 49913692; Tel: +3906 49913082

'Dipartimento di Chimica e Tecnologia del Farmaco, Università degli Studi La Sapienza, P. le A. Moro 5, I-00185 Roma, Italy

$\dagger$ Electronic supplementary information (ESI): ${ }^{1} \mathrm{H}-\mathrm{NMR}$ and ${ }^{13} \mathrm{C}-\mathrm{NMR}$ spectra of compounds 5, 6, 7, 8 and 9; computational methods and Cartesian coordinates of all the optimized molecular structures. See DOI: $10.1039 / \mathrm{c} 3 \mathrm{ra} 47753 \mathrm{c}$

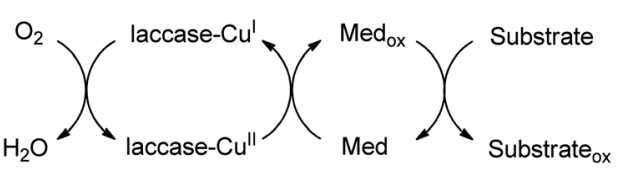

Scheme 1 The catalytic cycle of the laccase-mediator (Med) system. 
$(+)$-Catechin 1 and (-)-epicatechin 2 are representative members of flavonoids, a naturally occurring class of plant phenolic compounds widely distributed in foods and beverages, mainly in green and black tea (Fig. 1). ${ }^{7}$ Their biological and pharmacological effects, in particular radical scavenger activity, are well known. In the last few years, a synthetic catechin analogue in which the chroman and catechol moieties of $\mathbf{1}$ are coplanar by formation of a bridge between the 3-OH group on ring $\mathrm{C}$ and $\mathrm{C}-\mathrm{6}^{\prime}$ on ring $\mathrm{B}$ has been identified as a novel and efficient antioxidant with reduced pro-oxidant activity potentially useful for the prevention and treatment of free radicalassociated diseases. ${ }^{8}$

The enzymatic oxidations of polyphenols, and in particular of catechins, are widely described in the literature, being implicated in numerous biological processes in the vegetal world. ${ }^{9}$ In contrast, only a few articles have reported on the oxidative enzyme-catalysed chemistry of catechin derivatives for synthetic purposes. ${ }^{10}$ This lack of literature data is mainly due to the complexity of the reaction mixtures and the corresponding difficulties in isolating final oxidation products that are generally dimeric, oligomeric and polymeric compounds.

Taking into consideration our recent results regarding the oxidation of methylated catechins $\mathbf{3}$ and $\mathbf{4}$ with Trametes villosa laccase using 1-hydroxybenzotriazole (HBT) as mediator ${ }^{11}$ and as part of our research devoted to the selective oxidation of natural compounds in order to obtain fine chemicals and bioactive compounds, ${ }^{12}$ we projected the synthesis of new taxifolin-like compounds from methylated planar catechin $\mathbf{5}$ and methylated bent epicatechin derivative 6. Methylated catechin derivative 5 shows the $\mathrm{B}$ and $\mathrm{C}$ rings coplanar because of the formation of a trans junction between the $\mathrm{C}$ ring and the newly generated six-term cycle $\mathrm{D}$, in turn condensed to ring $\mathrm{B}$ according to the synthetic catechin analogue reported by Fukuhara (Fig. 1). ${ }^{8}$ Contrarily, due to the establishment of a cis junction between the $\mathrm{C}$ ring and the newly formed cycle $\mathrm{D}$, in its two more stable conformations modelled by DFT calculations (see below), methylated epicatechin derivative 6 presents bent geometry. The unexpected observed different chemoselectivity

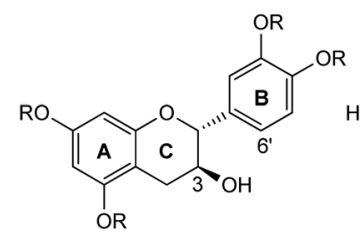

1: $\mathrm{R}=\mathrm{H} ; 3: \mathrm{R}=\mathrm{CH}_{3}$

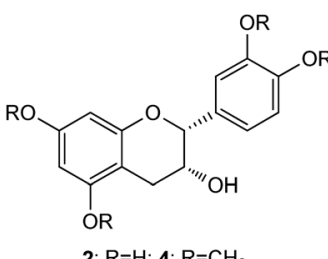

2: $\mathrm{R}=\mathrm{H} ; \mathbf{4}: \mathrm{R}=\mathrm{CH}_{3}$
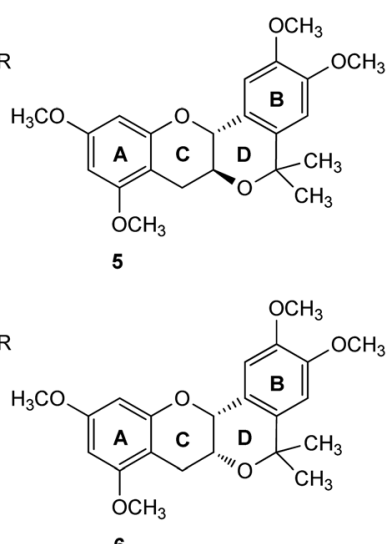

Fig. 1 Chemical structures of natural and synthetic catechin derivatives. of oxidation of methylated planar catechin 5 and bent epicatechin $\mathbf{6}$ has been rationalized using a molecular modelling approach.

\section{Results and discussion}

\section{Synthetic aspects}

Catechin and epicatechin derivatives 5 and $\mathbf{6}$ were synthesized via an oxa-Pictet-Spengler reaction from the corresponding tetramethylated catechin 3 and epicatechin $\mathbf{4}$ in acetone using $\mathrm{BF}_{3}-\mathrm{Et}_{2} \mathrm{O}$ as Lewis acid (Scheme 2) according to Fukuhara's protocol. $^{8,13}$

Next, we focused our attention on their behaviour in air and in the presence of Trametes villosa laccase/HBT as the catalytic system. Based on our previous study on the oxidation of catechins 3 and $4,{ }^{11}$ we initially chose aqueous sodium acetate buffer/tetrahydrofuran as the reaction medium. Unfortunately, despite the retained activity of the enzyme in this medium, methylated planar catechin 5 was not soluble. Therefore, owing to inactivation of the enzyme when the content of watermiscible organic solvent in the system increases ${ }^{14}$ and in an effort to use laccase in the presence of an organic solvent, we decided to perform the oxidation of catechin derivative 5 by the Trametes villosa laccase/HBT system in two types of reaction medium: (i) an aqueous sodium acetate buffer/ethyl acetate biphasic system ${ }^{15}$ and (ii) a sodium dioctylsulfosuccinate salt (АOT) reverse micelle system in isooctane/chloroform..$^{16,17}$ In both these reaction environments, after $24 \mathrm{~h}$, the laccase/HBT oxidation of methylated planar catechin $\mathbf{5}$ afforded exclusively compound 7 in $82 \%$ and $79 \%$ yields, respectively (Scheme 3; Table 1 , entries 1 and 2), deriving from oxidation at the C-2 position.

In contrast, methylated bent epicatechin $\mathbf{6}$ was soluble in aqueous sodium acetate buffer/tetrahydrofuran, and after $50 \mathrm{~h}$ it afforded the oxidation products 8 and 9 in $64 \%$ and $18 \%$ yields, respectively (Scheme 4; Table 1, entry 3 ).

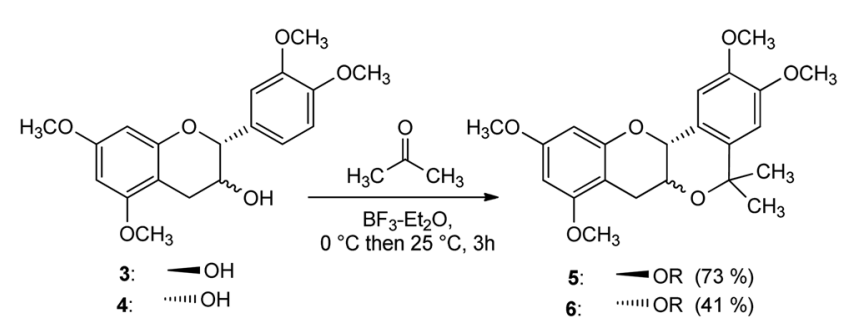

Scheme 2 Synthesis of methylated planar catechin 5 and methylated bent epicatechin 6 .

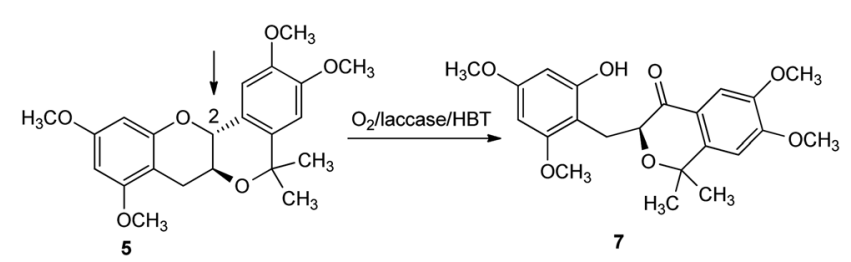

Scheme 3 Oxidation of methylated planar catechin derivative 5 . 
Table 1 Experimental data of oxidation of catechin derivatives 5 and 6

\begin{tabular}{|c|c|c|c|}
\hline Entry & Substrate & Reaction medium & Products (yield \%) \\
\hline 1 & 5 & NaOAc buffer/ethyl acetate ${ }^{a}$ & 7: 82 \\
\hline 2 & 5 & Isooctane/chloroform/AOT ${ }^{a}$ & 7: 79 \\
\hline 3 & 6 & $\begin{array}{l}\text { NaOAc buffer/ } \\
\text { tetrahydrofuran }^{b}\end{array}$ & 8: $64 ; 9: 18$ \\
\hline 4 & 6 & NaOAc buffer/ethyl acetate ${ }^{a}$ & 8: 71; 9: 21 \\
\hline 5 & 6 & Isooctane/chloroform/AOT ${ }^{a}$ & 8: 59; 9: traces \\
\hline
\end{tabular}

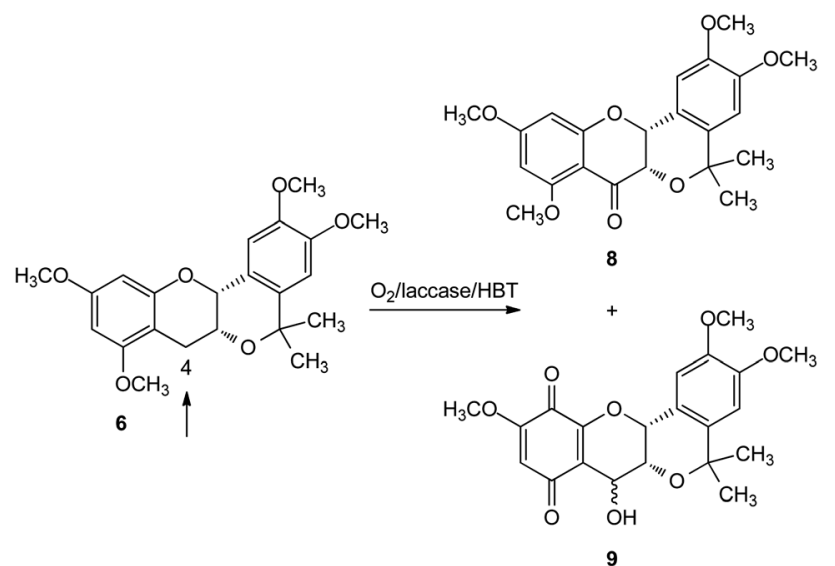

Scheme 4 Oxidation of methylated bent epicatechin derivative 6 .

Both products derive from oxidation at the C-4 position; compound $\mathbf{9}$ is a product of over-oxidation of the aromatic A ring.

The oxidation reactions conducted in the biphasic system and in the reverse micelle produced the same products 8 and $\mathbf{9}$ after only $24 \mathrm{~h}$ (Scheme 4; Table 1, entries 4 and 5). As far as we know, this is the first description of an oxidation reaction catalysed by the laccase/HBT system in either a biphasic system or a reverse micelle environment for synthetic purposes. Of note, the oxidation of methylated planar catechin derivative $\mathbf{5}$ and bent epicatechin 6 in these reaction media indicates that HBT acts as a "shuttle" connecting the organic phase, where substrates 5 and $\mathbf{6}$ are soluble, and the aqueous phase, where laccase retains its catalytic activity (Scheme 5). The use of these reaction media offers the additional advantage that further laccase addition during the oxidation is not necessary, as is required for the aqueous sodium acetate buffer/tetrahydrofuran medium (see Experimental section). ${ }^{\mathbf{1 1}}$

The experimental data evidence that oxidation of methylated bent epicatechin 6 by the laccase/HBT system leads to C-4 functionalization, in accordance with our previous results obtained by oxidation of methylated catechins 3 and $\mathbf{4 .}^{\mathbf{1 1}}$ Unexpectedly, methylated planar catechin $\mathbf{5}$ is oxidized on the C-2 position. These results demonstrate the synthetic potentiality of the oxidative procedure in flavonoid chemistry and, in general, medicinal chemistry in order to produce a rearranged core structure or a ketone derivative depending on the structural features. a) Biphasic system

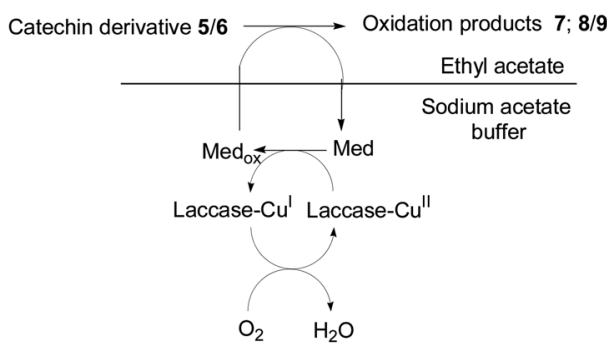

b) Reverse micelle

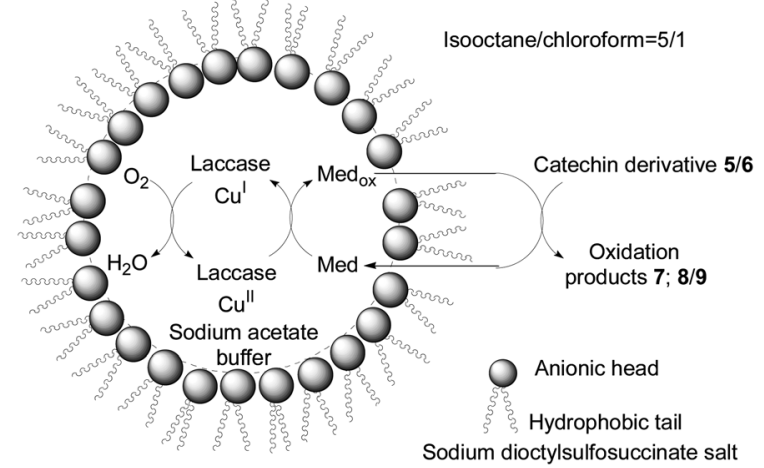

Scheme 5 Oxidation of catechin derivatives 5 and 6 in (a) the biphasic system and (b) the reverse micelle.

\section{Mechanistic aspects}

To shed light on such an intriguing finding, we undertook studies to investigate more precisely the origin of this different chemoselectivity. As described in the literature regarding the oxidation of a benzylic alcohol or ether derivatives by the laccase/HBT system, the key step is the abstraction of a hydrogen atom from the benzylic position by the oxidized form of the mediator, the benzotriazole- $N$-oxyl (BTNO) radical (Scheme 6). ${ }^{6}$

a. Determination of oxidation potential. Redox features of the substrate have no major impact upon this radical $\mathrm{H}$-atom transfer (HAT) route, where only the enthalpic balance between the breaking and forming of bonds is relevant. ${ }^{6}$

Indeed, determination of the oxidation potential by cyclic voltammetry in acetonitrile containing tetrabutylammonium tetrafluoroboride as supporting electrolyte indicated that methylated catechin and epicatechin derivatives 5 and 6 were irreversibly oxidized at a potential above $1.65 \mathrm{~V}$ (Table 2), thus confirming that they are resistant to monoelectronic oxidation

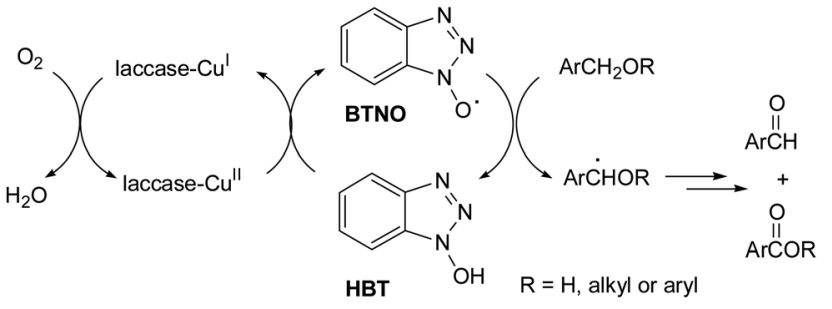

Scheme 6 Catalytic cycle of the laccase/HBT system in the oxidation of a benzylic alcohol or ether derivatives. 
Table 2 Oxidation potential, rate constant $k_{\mathrm{H}}$ and dissociation energies of $\mathrm{C}-2-\mathrm{H}$ and $\mathrm{C}-4-\mathrm{H}$ bonds of catechin derivatives 5 and 6

\begin{tabular}{|c|c|c|c|c|c|c|c|}
\hline \multirow[b]{2}{*}{ Sub } & \multirow[b]{2}{*}{$E^{\mathrm{P}}(\mathrm{V}, v s . \mathrm{NHE})^{a}$} & \multirow[b]{2}{*}{$k_{\mathrm{H}}\left(\mathrm{M}^{-1} \mathrm{~s}^{-1}\right)^{b}$} & \multirow[b]{2}{*}{ Sub.conf. $^{c}$} & \multicolumn{4}{|c|}{$\mathrm{BDE}_{\mathrm{C}-\mathrm{H}}\left(\mathrm{kJ} \mathrm{mol}^{-1}\right)^{d}$} \\
\hline & & & & $\mathrm{HF}^{e}$ & DFT2 $/ / \mathrm{HF}^{f}$ & $\mathrm{DFT}^{g}$ & $\mathrm{DFT} 2 / / \mathrm{DFT}^{h}$ \\
\hline $\mathbf{5}_{\mathrm{C}-2}\left(1^{i}\right)$ & 1.75 & $61 \pm 1$ & $\mathbf{5}_{\mathrm{C}-2}$ & 259.6 & 355.7 & 360.7 & 359.6 \\
\hline $\mathbf{5}_{\mathrm{C}-4}\left(2^{i}\right)$ & & & $\mathbf{5}_{\mathrm{C}-4}$ & 291.4 & 380.1 & 385.3 & 381.9 \\
\hline $6_{\mathrm{C}-2}\left(1^{i}\right)$ & 1.69 & $56 \pm 1$ & $6 \mathbf{a}_{\mathrm{C}-2}$ & 244.6 & 350.6 & 354.5 & 355.2 \\
\hline \multirow{3}{*}{$6_{\mathrm{C}-4}\left(2^{i}\right)$} & & & $6 a_{C-4}$ & 289.4 & 370.4 & 378.9 & 373.2 \\
\hline & & & $6 \mathbf{b}_{\mathrm{C}-2}$ & 268.7 & & 358.6 & \\
\hline & & & $\mathbf{6 b}_{\mathrm{C}-4}$ & 281.3 & & 375.4 & \\
\hline
\end{tabular}

${ }^{a}$ [Substrate]: $2 \mathrm{mM}$, at $500 \mathrm{mV} \mathrm{s}^{-1}$ in $\mathrm{CH}_{3} \mathrm{CN}$ containing $\mathrm{Bu}_{4} \mathrm{NBF}_{4}(0.1 \mathrm{M}) .{ }^{b}$ Rate constants obtained spectrophotometrically at $25{ }^{\circ} \mathrm{C}$ in $\mathrm{CH}_{3} \mathrm{CN}$; initial condition: $[\mathrm{BTNO}]=0.5 \mathrm{mM}$, [substrate] $=5-40 \mathrm{mM}$; determination in triplicate. ${ }^{c}$ Calculated conformations of substrate. ${ }^{d}$ From the following equation: $\mathrm{BDE}_{\mathrm{C}-\mathrm{H}}=\Delta H_{\mathrm{f}}^{\circ}(\mathrm{R})+\Delta H_{\mathrm{f}}^{\circ}(\mathrm{H})-\Delta H_{\mathrm{f}}^{\circ}(\mathrm{R}-\mathrm{H}) ; \Delta H_{\mathrm{f}}^{\circ}(\mathrm{H})=218.0 \mathrm{~kJ} \mathrm{~mol}^{-1} .^{21}{ }^{e} \mathrm{HF} / 3-21 \mathrm{G} .{ }^{f} \mathrm{~B} 3 \mathrm{LYP} / 6-311+\mathrm{G} * * / / \mathrm{HF} / 3-21 \mathrm{G} .{ }^{g} \mathrm{~B} 3 \mathrm{LYP} / 6-$ $31 \mathrm{G}^{*} .{ }^{h} \mathrm{~B} 3 \mathrm{LYP} / 6-311+\mathrm{G}^{* *} / / \mathrm{B} 3 \mathrm{LYP} / 6-31 \mathrm{G}^{*} .{ }^{i}$ Number of equivalent $\mathrm{H}$ atoms.

and cannot be oxidized by Trametes villosa laccase $\left(E^{\circ} 0.79 \mathrm{~V} /\right.$ $\mathrm{NHE})^{18}$ directly.

b. H-abstraction reactivity. We focused our efforts on investigating the HAT reactivity $\left(k_{\mathrm{H}}\right)$ of BTNO from methylated catechin derivatives 5 and $\mathbf{6}$ by using UV-Vis spectroscopy and monitoring the disappearance of the $\mathrm{OD}$ at $\lambda=474 \mathrm{~nm}\left(\mathrm{OD}_{474}\right)$ of BTNO under reported conditions in $\mathrm{CH}_{3} \mathrm{CN}$ solution at 25 ${ }^{\circ} \mathrm{C} .{ }^{\mathbf{1 1 , 1 9}}$ Briefly, BTNO was generated in the spectrophotometric cuvette by quickly mixing a $0.5 \mathrm{mM}$ solution of monoelectronic oxidant $\left(\mathrm{NH}_{4}\right)_{2} \mathrm{Ce}\left(\mathrm{NO}_{3}\right)_{6}(\mathrm{CAN})$ with a $0.5 \mathrm{mM}$ HBT solution, both in $\mathrm{CH}_{3} \mathrm{CN}$ at $25{ }^{\circ} \mathrm{C}$. The reading of the initial absorption at $\lambda=474 \mathrm{~nm}$ confirmed quantitative generation of BTNO. Rapid addition of a solution of the $\mathrm{C}-\mathrm{H}$-bearing compound marked the beginning of the kinetic experiment; 3-5 initial concentrations of the substrate were typically investigated at concentrations exceeding that of BTNO by 10-80-fold. The time-dependent depletion of BTNO at $\mathrm{OD}_{474}$ was monitored by stopped-flow spectrophotometry because the reaction times were generally in the few seconds range. Under these pseudo first-order conditions, the $\mathrm{H}$-abstraction rate from the substrate was higher than the spontaneous decay of BTNO $\left(k_{\text {decay }}=6.3 \times 10^{-3} \mathrm{~s}^{-1}\right) \cdot{ }^{19}$ The pseudo first-order rate constants $k_{0}$, determined from at least duplicated experiments, were converted into second-order $\mathrm{H}$ abstraction rate constants $\left(k_{\mathrm{H}}\right)$ by determining the slope of a $k_{0}$ versus $[\text { subst }]_{0}$ linear plot (Table 2). As expected, methylated catechin derivative $\mathbf{5}$ is about twice more reactive than epicatechin derivative $6\left(k_{\mathrm{H}} /\right.$ number of equivalent $\mathrm{H}$ atoms = $61 \mathrm{M}^{-1} \mathrm{~s}^{-1}$ and $28 \mathrm{M}^{-1} \mathrm{~s}^{-1}$, respectively) due to the presence, in the first one of the two, of the lone-pair of the oxygen atom O-1 that weakens the adjacent $\mathrm{C}-2-\mathrm{H}$ bond and stabilizes the intervening C-2-radical generated by $\mathrm{H}$-abstraction. ${ }^{20}$

\section{Rationalization of the observed chemoselectivity}

Estimations of $\mathrm{BDE}_{\mathrm{C}-\mathrm{H}}$ values for $\mathrm{H}$-abstraction from the $\mathrm{C}-2$ or C-4 position of each compound 5 and 6 (one representative conformation for $\mathbf{5}$ and two for $\mathbf{6}$, hereafter denoted as $\mathbf{6 a}$ and 6b) were performed by quantum chemical calculations based on the hybrid Hartree-Fock (HF)/Density Functional Theory (DFT) method (for details see ESI $\dagger$ ). Similar to what was previously observed for the parent structures 3 and $\mathbf{4},{ }^{11}$ the achieved $\mathrm{BDE}_{\mathrm{C}-\mathrm{H}}$ values (Table 2) indicated for both planar and bent catechin tetramethyl ethers $\mathbf{5}$ and $\mathbf{6}$ a more advantageous $\mathrm{H}$-abstraction from carbon C-2 (359.6 and $355.2 \mathrm{~kJ} \mathrm{~mol}^{-1}$, respectively) than from C-4 (381.9 and $373.2 \mathrm{~kJ} \mathrm{~mol}^{-1}$, respectively). Moreover, the values attributed to the $\mathrm{C}-2$ radical formation were found to be even smaller than those calculated elsewhere for 3 and 4 (377.4 and $367.4 \mathrm{~kJ} \mathrm{~mol}{ }^{-1}$, respectively). ${ }^{11}$ However, such findings can only explain the $\mathrm{C}-2$ functionalization observed in the oxidation of the planar catechin 5 , but do not justify the reactivity manifested by compound $\mathbf{6}$ that led to the formation of $\mathbf{8}$ and $\mathbf{9}$ (i.e. the reactivity at carbon $\mathrm{C}-4)$. Again, taking inspiration from our previous study involving, amongst others, catechins 3 and $4,{ }^{11}$ we theoretically evaluated the possibility that the observed C-4 reactivity of $\mathbf{6}$, assessed as thermodynamically disadvantageous, may originate from kinetic factors. For this purpose, four relevant transition states (TS) simulating $\mathrm{H}$-abstraction from either the $\mathrm{C}-2$ or $\mathrm{C}-4$ position of $\mathbf{5}$ and $\mathbf{6 a}$ were also modelled (i.e. the structures hereafter denoted as TS_5 $\mathbf{5}_{\mathrm{C}-2}-\mathrm{BTNO}, \mathrm{TS} \_\mathbf{5}_{\mathrm{C}-4}-\mathrm{BTNO}$, TS_6 $a_{\mathrm{C}-2}-\mathrm{BTNO}$ and TS_6 $\mathbf{a}_{\mathrm{C}-4}-\mathrm{BTNO}$; Fig. S1; $\dagger$ details are given in the Experimental section and ESI $\dagger$ ). From inspection of the achieved energetic results (Table S1 of ESI $\dagger$ ), it is clear that methylated catechin and epicatechin derivatives 5 and 6 (in its more stable and greatly dominant 6 a conformation) display a very different reactive behaviour towards oxidation. Indeed, catechin 5 shows an energetically more favourable and then faster $\mathrm{H}$-abstraction from the C-2 carbon atom $\left(\Delta \Delta E_{\mathrm{C}-2-\mathrm{C}-4}{ }^{5}=\right.$ $E_{\mathrm{TS} \_5 \mathrm{C}-2-\mathrm{BTNO}}-E_{\mathrm{TS} \_5 \mathrm{C}-4-\mathrm{BTNO}}=-12.30 \mathrm{~kJ} \mathrm{~mol}^{-1}$ from M06-2x calculations), whereas this occurs from the C-4 position for epicatechin $6\left(\Delta \Delta E_{\mathrm{C}-2-\mathrm{C}-4}{ }^{6}=E_{\mathrm{TS} \_6 a C-2-\mathrm{BTNO}}-\mathrm{E}_{\mathrm{TS} \_6 a C-4-\mathrm{BTNO}}=\right.$ $10.85 \mathrm{~kJ} \mathrm{~mol}^{-1}$ from M06-2x calculations). This means that, at $25{ }^{\circ} \mathrm{C}$ and referring both the C-2 and C-4 HAT transition states of each catechin 5 or 6 to a relevant and common ground state adduct (hereafter denoted as 5:BTNO and 6a:BTNO, respectively), for compound 5 the generation of radical C-2 is assessed about 143 times faster than that of radical C-4, whereas for compound 6 it is estimated that radical C-2 is generated about 80 times slower than radical C-4. Interestingly, stable ground states of complexes 5:BTNO and 6a:BTNO displaying the BTNO oxygen virtually equidistant from both hydrogen atoms linked to carbons C-2 and C-4 (i.e. just geometries eligible to be considered as the common starting point leading to both transition states 


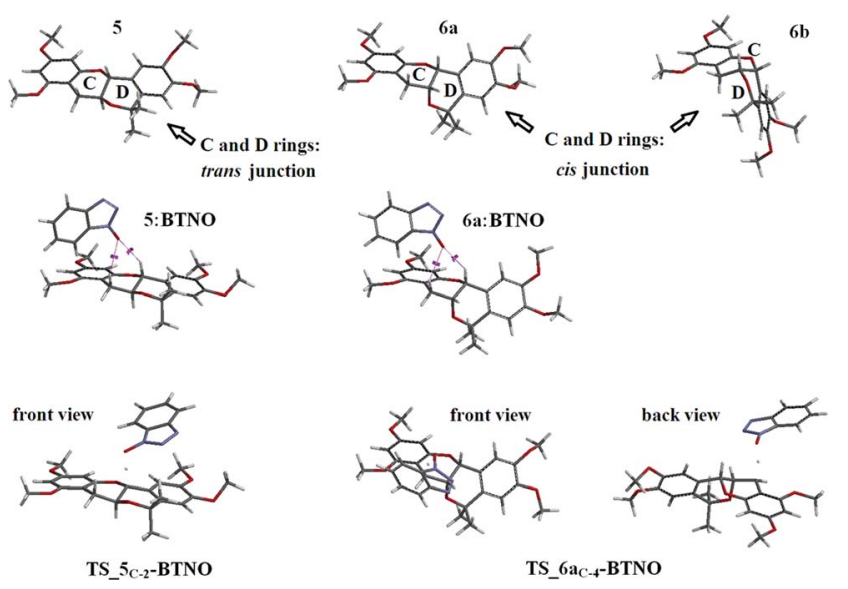

Fig. 2 Calculated structures of methylated planar catechin 5 and methylated bent epicatechin 6 in their free states (top position); ground state adducts with BTNO (middle position); and transition state adducts with BTNO (bottom position).

TS_ $\boldsymbol{X}_{\mathrm{C}-2}$-BTNO and TS_ $\boldsymbol{X}_{\mathrm{C}-4}$-BTNO, with $\boldsymbol{X}$ being equal to 5 or $\mathbf{6}$; Fig. 2 and ES1 $\dagger$ ) have indeed been obtained by suitable optimization at equilibrium geometry level of the structures TS_5 $\mathbf{5}_{\mathrm{C}-2}$-BTNO and TS_6 $\mathbf{a}_{\mathrm{C}-4}$-BTNO.

Therefore, in the case of epicatechin 6, the whole of the quoted findings resolutely agrees with the interpretation of a kinetic control of the process prevailing on the thermodynamic one, providing in this way a theoretical persuasive rationalization of the differential chemoselective oxidizability displayed by compounds 5 and 6. By visual analysis of the optimized structures obtained for $\mathrm{TS}_{-} \mathbf{5}_{\mathrm{C}-2}$-BTNO, TS_5 $\mathbf{5}_{\mathrm{C}-4}{ }^{-}$ BTNO, TS_6 $\mathbf{a}_{\mathrm{C}-2}-\mathrm{BTNO}$ and TS_6 $\mathbf{a}_{\mathrm{C}-4}-\mathrm{BTNO}$, a more direct relationship due to steric effects can be established between the observed chemoselectivity and the planar or bent structure of the considered catechins, as described in detail in the ESI. $\dagger$

\section{Conclusions}

Unreported methylated planar catechin and bent epicatechin derivatives 5 and $\mathbf{6}$ were synthesized via an oxa-Pictet-Spengler reaction and then oxidized in air using Trametes villosa laccase/ 1-hydroxybenzotriazole as the catalytic system. The oxidations were performed in a biphasic system and in a reverse micelle and were determined to be chemoselective and efficient. To the best of our knowledge, this is the first time an exploitation of laccase/mediator in these reaction media for synthetic purposes has been reported. The different chemoselective oxidations of methylated planar catechin 5 (at the C-2 position) and bent epicatechin derivative 6 (at the C-4 position) were rationalized using a molecular modelling approach.

\section{Experimental}

\section{Materials and instruments}

All chemicals were of the highest commercially available quality and were used as received. Crude laccase from Trametes villosa (Novozym 51002) was a gift from Novo Nordisk Co. and was free of lignin or manganese peroxidases. ${ }^{1} \mathrm{H}$ NMR and ${ }^{13} \mathrm{C}$ NMR spectra were recorded on a spectrometer 200 and $300 \mathrm{MHz}$ using $\mathrm{CDCl}_{3}$ as solvent. All chemical shifts are expressed in parts per million ( $\delta$ scale) and coupling constants are in Hertz (Hz). HPLC analysis was performed with a C18 column $(150 \mathrm{~mm}$ $\times 4.6 \mathrm{~mm} \times 5 \mu \mathrm{m}$ ) and a UV detector at $\lambda=280 \mathrm{~nm}$. Samples

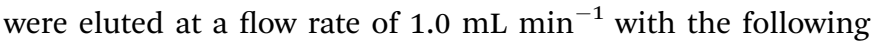
method: acetonitrile/water $=10 / 90(0-10 \mathrm{~min})$; linear gradient until a ratio of acetonitrile/water $=60 / 40$ (10-25 $\mathrm{min})$; acetonitrile/water $=60 / 40(5 \mathrm{~min})$; linear gradient until a ratio of acetonitrile/water $=80 / 20(30-35 \mathrm{~min})$ and then acetonitrile/ water $=80 / 20(5 \mathrm{~min})$. High-resolution mass spectra (HRMS) were performed with an Electrospray Ionization Time of Flight Micromass spectrometer. Kinetic studies were performed with a stopped flow instrument interfaced to a diode array spectrophometer having a thermostated cuvette holder.

\section{Purification of laccase}

Laccase from a strain of Trametes villosa (viz. Poliporus pinsitus) (Novo Nordisk Biotech) was employed. It was purified by ionexchange chromatography on a Q-Sepharose column (preequilibrated with $10 \mathrm{mM}$ Tris-HCl buffer at $\mathrm{pH} 7.5,1 \mathrm{mS}$ ) by elution with a mixture of $10 \mathrm{mM}$ Tris- $\mathrm{HCl}$ and $0.2 \mathrm{M} \mathrm{NaCl}$ (linear gradient 1-70 $\mathrm{mM} \mathrm{NaCl}$ ); laccase fractions having an absorption ratio $A_{280} / A_{610}$ of $20-30$ were considered sufficiently pure. $^{22}$ The collected fractions were concentrated by dialysis in cellulose membrane tubing (Sigma) against poly(ethylene glycol) to a final activity of $5277 \mathrm{U} \mathrm{mL}^{-1}$, as determined spectrophotometrically by the standard assay with ABTS (where $1 \mathrm{U}$ is the number of $\mu \mathrm{mol}$ of ABTS oxidized by $1 \mathrm{~mL}$ of laccase solution per $\min ) .{ }^{23}$

\section{Synthesis of catechin and epicatechin derivatives}

(a). Synthesis of tetramethylated catechin 3 and epicatechin 4. (+)-Catechin 1 or epicatechin $2(290 \mathrm{mg}, 1.0 \mathrm{mmol})$ was solubilized in acetone $(10 \mathrm{~mL})$ at $25{ }^{\circ} \mathrm{C}$. Potassium carbonate $(828 \mathrm{mg}, 6.0 \mathrm{mmol})$ and dimethyl sulfate $(3.15 \mathrm{~g}, 25$ $\mathrm{mmol}$ ) were then added. After $24 \mathrm{~h}$, the substrate disappeared and the solvent was evaporated under reduced pressure. The mixture was neutralized with $1 \mathrm{M} \mathrm{HCl}$; it was then extracted with ethyl acetate. The organic phases were recombined and dried over $\mathrm{Na}_{2} \mathrm{SO}_{4}$. Following evaporation of the solvent and chromatographic purification of the product on silica gel (eluent: ethyl acetate/hexane $=1: 1$ ), methylated catechin 3 and 4 were isolated and characterized by spectroscopic analysis.

Methylated catechin 3. Yellow solid (339 mg, 98\%), mp 142$144{ }^{\circ} \mathrm{C}$ (from acetone/hexane). Spectroscopic data were identical with those in the literature. ${ }^{24}$

Methylated epicatechin 4. Yellow solid (329 mg, 95\%), mp 144$146^{\circ} \mathrm{C}$ (from acetone/hexane). Spectroscopic data were identical with those in the literature. ${ }^{24}$

(b). Synthesis of methylated planar catechin 5 and methylated bent epicatechin 6. The synthesis was performed according to Fukuhara procedure. ${ }^{13}$ Briefly, $2.56 \mathrm{~mL}$ of $\mathrm{BF}_{3}-\mathrm{Et}_{2} \mathrm{O}$ solution $\left(2.87 \mathrm{~g}, d=1.12 \mathrm{~g} \mathrm{~mL}^{-1}\right)$ was added at $0{ }^{\circ} \mathrm{C}$ to a solution of $1 \mathrm{~g}(2.9 \mathrm{mmol})$ of compound 3 or 4 in $120 \mathrm{~mL}$ di acetone. The 
reaction mixture was stirred for $3 \mathrm{~h}$ at room temperature then diluted with diethyl ether. The organic solution was washed with brine, dried over $\mathrm{Na}_{2} \mathrm{SO}_{4}$, filtered and concentrated in vacuum. The residue was purified by silica gel (Merck, silica gel 60, 230-400 mesh) column chromatography using hexane/ethyl acetate $=5 / 1$ as eluent. Products 5 and 6 were characterized by spectroscopic analysis.

Methylated planar catechin 5. White power (817 mg, 73\%), mp: $136-138{ }^{\circ} \mathrm{C}$ (from acetone/hexane). Anal. Found: $\mathrm{C}, 68.2 ; \mathrm{H}$, 6.8; O: 25.0. Calcd. for $\mathrm{C}_{22} \mathrm{H}_{26} \mathrm{O}_{6}: \mathrm{C}, 68.4 ; \mathrm{H}, 6.8$; O, $24.8 \% .{ }^{1} \mathrm{H}-$ $\operatorname{NMR}\left(\mathrm{CDCl}_{3}\right): \delta 1.57\left(6 \mathrm{H}, \mathrm{s}, 2 \times \mathrm{CH}_{3}\right), 2.56\left(1 \mathrm{H}, \mathrm{dd}, J_{1}=16 \mathrm{~Hz}\right.$, $\left.J_{2}=10 \mathrm{~Hz}, 4-H\right), 3.07\left(1 \mathrm{H}, \mathrm{dd}, J_{1}=16 \mathrm{~Hz}, J_{2}=6.0 \mathrm{~Hz}, 4-H\right), 3.80$ $\left(7 \mathrm{H}, \mathrm{bs}, 2 \times \mathrm{OCH}_{3}, 3-\mathrm{H}\right), 3.89\left(3 \mathrm{H}, \mathrm{s}, \mathrm{OCH}_{3}\right), 3.96\left(3 \mathrm{H}, \mathrm{s}, \mathrm{OCH}_{3}\right)$, $4.63(1 \mathrm{H}, \mathrm{d}, J=8.0 \mathrm{~Hz}, 2-H), 6.12(1 \mathrm{H}, \mathrm{s}, 8-H), 6.20(1 \mathrm{H}, \mathrm{s}, 6-H)$, $6.56\left(1 \mathrm{H}, \mathrm{s}, 5^{\prime}-H\right), 7.17\left(1 \mathrm{H}, \mathrm{s}, 2^{\prime}-H\right) .{ }^{13} \mathrm{C}-\mathrm{NMR}\left(\mathrm{CDCl}_{3}\right): \delta 26.9$, 28.1, 31.6, 55.4, 55.5, 56.0, 56.1, 66.3, 73.3, 75.8, 91.9, 93.2, 102.5 , 107.7, 108.0, 125.0, 135.1, 147.9, 148.5, 155.3, 158.9, 159.6.

Methylated bent epicatechin 6. White power (459 mg, 41\%), $\mathrm{mp} 146-148{ }^{\circ} \mathrm{C}$ (from diethyl ether/hexane). Anal. Found: $\mathrm{C}$, 68.1; $\mathrm{H}, 7.0 ; \mathrm{O}, 24.9$. Calcd. for $\mathrm{C}_{22} \mathrm{H}_{26} \mathrm{O}_{6}: \mathrm{C}, 68.4 ; \mathrm{H}, 6.8: \mathrm{O}$, $24.8 \% .{ }^{1} \mathrm{H}-\mathrm{NMR}\left(\mathrm{CDCl}_{3}\right): \delta 1.51\left(3 \mathrm{H}, \mathrm{s}, \mathrm{CH}_{3}\right), 1.53\left(3 \mathrm{H}, \mathrm{s}, \mathrm{CH}_{3}\right)$, $2.89(2 \mathrm{H}, \mathrm{d}, J=4.0 \mathrm{~Hz}, 4-H), 3.70\left(3 \mathrm{H}, \mathrm{s}, \mathrm{OCH}_{3}\right), 3.73(3 \mathrm{H}, \mathrm{s}$, $\left.\mathrm{OCH}_{3}\right), 3.87\left(3 \mathrm{H}, \mathrm{s}, \mathrm{OCH}_{3}\right), 3.90\left(3 \mathrm{H}, \mathrm{s}, \mathrm{OCH}_{3}\right), 4.27(1 \mathrm{H}, \mathrm{m}, 3-\mathrm{H})$, $4.56(1 \mathrm{H}, \mathrm{bs}, 2-H), 6.05(2 \mathrm{H}, \mathrm{m}, 6,8-H), 6.62\left(1 \mathrm{H}, \mathrm{s}, 5^{\prime}-H\right), 6.86$ $\left(1 \mathrm{H}, \mathrm{s}, 2^{\prime}-H\right) .{ }^{13} \mathrm{C}-\mathrm{NMR}\left(\mathrm{CDCl}_{3}\right): \delta 25.6,27.6,31.6,55.3,55.4$, 56.0, 56.1, 63.3, 70.8, 75.5, 91.6, 93.2, 100.5, 108.3, 112.3, 123.9, 136.0, 147.8, 149.8, 155.0, 158.8, 159.3.

\section{Oxidation of methylated planar catechin (5) and methylated bent epicatechin (6)}

(a). Oxidations in sodium acetate buffer/ethyl acetate (biphasic system). Reactions were performed in air at $25{ }^{\circ} \mathrm{C}$ in magnetically stirred $1: 1(\mathrm{v} / \mathrm{v})$ buffered water $(\mathrm{pH} 4.7,0.05 \mathrm{M}$ $\mathrm{NaOAc}$ )/ethyl acetate. Compound 5 (or 6, $14 \mathrm{mg}, 40 \mu \mathrm{mol}$ ) was solubilized in $2.0 \mathrm{~mL}$ of reaction medium, followed by the addition of 1-hydroxybenzotriazole HBT $(5.4 \mathrm{mg}, 40 \mu \mathrm{mol})$ and laccase (40 U). Reactions were monitored by TLC analysis. At the end of the experiment ( $24 \mathrm{~h})$, the internal standard (1-methyl-6methoxy-3,4-dihydro-1H-isochromen-7-ol, $7.8 \mathrm{mg}, 40 \mu \mathrm{mol})^{11}$ was added. The organic phase was separated and the water phase was further extracted with ethyl acetate; the combined organic phases were washed with a saturated solution of $\mathrm{NaCl}$ and dried over $\mathrm{Na}_{2} \mathrm{SO}_{4}$. The yields of the oxidation reactions were determined by HPLC analysis with the internal standard method; suitable response factors were determined from authentic products. Pure samples of compound 7 (or 8 and 9) were obtained after chromatographic purifications using mixtures of hexane/ethyl acetate $=1 / 1(\mathrm{v} / \mathrm{v})$ and dichloromethane/methanol $=98 / 2(\mathrm{v} / \mathrm{v})$ and characterized by spectroscopic and analytical data.

(b). Oxidations in isooctane/chloroform/sodium dioctylsulfosuccinate salt (AOT) (reverse micelle). Compound 5 (or 6, $14 \mathrm{mg}, 40 \mu \mathrm{mol}$ ) was solubilized in $2.1 \mathrm{~mL}$ of sodium dioctyl sulfosuccinate sodium salt $(0.2 \mathrm{M})$ /isooctane/chloroform 5/1 $(\mathrm{v} / \mathrm{v})$ mixture; an aqueous solution of laccase $(40 \mathrm{U}$ in $0.113 \mathrm{~mL}$ of 0.05 sodium acetate buffer $\mathrm{pH} 4.7$ ) was added and thus reverse micelle solution was prepared $\left(W_{\mathrm{o}}=15\right) .{ }^{17}$ After the addition of HBT $(5.4 \mathrm{mg}, 40 \mu \mathrm{mol})$ the reaction was stirred at $25{ }^{\circ} \mathrm{C}$ for $24 \mathrm{~h}$. Reactions were monitored by TLC analysis. At the end of the experiment, the internal standard (1-methyl-6-methoxy3,4-dihydro- $1 H$-isochromen-7-ol, $7.8 \mathrm{mg}, 40 \mu \mathrm{mol})^{11}$ was added and the reaction vessel was dipped into a hot water bath (70-80 $\left.{ }^{\circ} \mathrm{C}\right)$ to denature the enzyme. The crude was diluted with acetonitrile. The yields of the oxidation reactions were determined by HPLC analysis with the internal standard method; suitable response factors were determined from authentic products.

(c). Oxidation in sodium acetate buffer/tetrahydrofuran. Reaction was performed in air at $25{ }^{\circ} \mathrm{C}$ in magnetically stirred $1: 1(\mathrm{v} / \mathrm{v})$ buffered water ( $\mathrm{pH} 4.7,0.05 \mathrm{M}$ sodium acetate)/THF. Compound $6(14 \mathrm{mg}, 40 \mu \mathrm{mol})$ was solubilized in $2.0 \mathrm{~mL}$ of reaction medium, followed by the addition of HBT $(5.4 \mathrm{mg}$, $40 \mu \mathrm{mol})$ and laccase (40 U). Additional aliquots of laccase (40 U) were added every $3 \mathrm{~h}$ up until $280 \mathrm{U}$. Reaction was monitored by TLC analysis. At the end of the experiment $(50 \mathrm{~h})$, the internal standard (1-methyl-6-methoxy-3,4-dihydro-1H-isochromen-7-ol, $7.8 \mathrm{mg}, 40 \mu \mathrm{mol})^{11}$ was added. The mixture was extracted with ethyl acetate; the organic phases were washed with a saturated solution of $\mathrm{NaCl}$ and dried over $\mathrm{Na}_{2} \mathrm{SO}_{4}$. The yield of the oxidation reaction was determined by HPLC analysis with the internal standard method; suitable response factors were determined from authentic products.

(S)-3-(2-Hydroxy-4, 6-dimethoxybenzyl)-6,7-dimethoxy-1,1-dimethylisochroman-4-one 7. Yellow oil. ${ }^{1} \mathrm{H}-\mathrm{NMR}\left(\mathrm{CDCl}_{3}\right): \delta 1.49(6 \mathrm{H}$, $\left.\mathrm{s}, 2 x \mathrm{CH}_{3}\right), 2.73\left(1 \mathrm{H}, \mathrm{dd}, J_{1}=15 \mathrm{~Hz}, J_{2}=9.0 \mathrm{~Hz}, \mathrm{CH}_{2}\right), 3.64(1 \mathrm{H}$, $\left.\mathrm{dd}, J_{1}=15 \mathrm{~Hz}, J_{2}=3.0 \mathrm{~Hz}, \mathrm{CH}_{2}\right), 3.71\left(3 \mathrm{H}, \mathrm{s}, \mathrm{OCH}_{3}\right), 3.74(3 \mathrm{H}, \mathrm{s}$, $\left.\mathrm{OCH}_{3}\right), 3.86\left(3 \mathrm{H}, \mathrm{s}, \mathrm{OCH}_{3}\right), 3.89\left(3 \mathrm{H}, \mathrm{s}, \mathrm{OCH}_{3}\right), 4.44\left(1 \mathrm{H}, \mathrm{dd}, J_{1}=\right.$ $\left.9.0 \mathrm{~Hz}, J_{2}=3.0 \mathrm{~Hz}, 3-H\right), 6.02\left(1 \mathrm{H}, \mathrm{d}, J=2.0 \mathrm{~Hz}, 5^{\prime}-H\right), 6.11(1 \mathrm{H}$, $\left.\mathrm{d}, J=2.0 \mathrm{~Hz}, 3^{\prime}-H\right), 6.52(1 \mathrm{H}, \mathrm{s}, 8-H), 7.41(1 \mathrm{H}, \mathrm{s}, 5-H), 8.33(1 \mathrm{H}$, $\mathrm{s}, \mathrm{OH}) .{ }^{13} \mathrm{C}-\mathrm{NMR}\left(\mathrm{CDCl}_{3}\right): \delta 24.9,26.3,29.7,55.2,55.7,56.1,56.2$, 75.6, 76.4, 91.3, 94.5, 101.9, 105.8, 108.2, 131.9, 143.9, 148.4, 154.3, 157.6, 159.0, 160.1, 193.8. HRMS (ESI-TOF) $m / z:[\mathrm{M}+\mathrm{Na}]^{+}$ Found 425.1576. Calcd. for $\mathrm{C}_{22} \mathrm{H}_{26} \mathrm{O}_{7} \mathrm{Na} 425.1590$.

(6aS,12aR)-2,3,8,10-Tetramethoxy-5,5-dimethyl-6a,12a-dihydroisochromeno[4,3-b]chromen-7(5H)-one 8. Yellow oil. ${ }^{1} \mathrm{H}-\mathrm{NMR}$ $\left(\mathrm{CDCl}_{3}\right): \delta 1.58\left(6 \mathrm{H}, \mathrm{s}, 2 x \mathrm{CH}_{3}\right), 3.81\left(3 \mathrm{H}, \mathrm{s}, \mathrm{OCH}_{3}\right), 3.89(3 \mathrm{H}, \mathrm{s}$, $\left.\mathrm{OCH}_{3}\right), 3.91\left(3 \mathrm{H}, \mathrm{s}, \mathrm{OCH}_{3}\right), 3.94\left(3 \mathrm{H}, \mathrm{s}, \mathrm{OCH}_{3}\right), 4.15(1 \mathrm{H}, \mathrm{d}, J=$ $2.0 \mathrm{~Hz}, 6 \mathrm{a}-H), 4.99(1 \mathrm{H}, \mathrm{d}, J=2.0 \mathrm{~Hz}, 12 \mathrm{a}-H), 6.08(1 \mathrm{H}, \mathrm{d}, J=3.0$ Hz, 11-H), $6.12(1 \mathrm{H}, \mathrm{d}, J=3.0 \mathrm{~Hz}, 9-H), 6.64(1 \mathrm{H}, \mathrm{s}, 4-H), 6.89$ $(1 \mathrm{H}, \mathrm{s}, 1-H) .{ }^{13} \mathrm{C}-\mathrm{NMR}\left(\mathrm{CDCl}_{3}\right): \delta 27.8,31.3,55.9,56.3,56.4,56.5$, 71.5, 73.9, 76.4, 93.5, 93.6, 105.0, 108.3, 112.4, 120.7, 136.6, 148.4, 150.7, 163.3, 165.0, 166.7, 186.0. HRMS (ESI-TOF) $\mathrm{m} / \mathrm{z}$ : [M $+\mathrm{Na}]^{+}$Found 423.1420. Calcd. for $\mathrm{C}_{22} \mathrm{H}_{24} \mathrm{O}_{7} \mathrm{Na} 423.1457$.

(6aR,12aR)-7-Hydroxy-2,3,10-trimethoxy-5,5-dimethyl-6a,7-dihydroisochromeno[4,3-b]chromene-8,11(5H,12aH)-dione 9. Yellow oil. ${ }^{1} \mathrm{H}-\mathrm{NMR}\left(\mathrm{CDCl}_{3}\right): \delta 1.54\left(3 \mathrm{H}, \mathrm{s}, \mathrm{CH}_{3}\right), 1.58\left(3 \mathrm{H}, \mathrm{s}, \mathrm{CH}_{3}\right), 3.76$ $\left(3 \mathrm{H}, \mathrm{s}, \mathrm{OCH}_{3}\right), 3.88\left(3 \mathrm{H}, \mathrm{s}, \mathrm{OCH}_{3}\right), 3.89\left(3 \mathrm{H}, \mathrm{s}, \mathrm{OCH}_{3}\right), 4.17(1 \mathrm{H}, \mathrm{d}$, $J=2.0 \mathrm{~Hz}, 12 \mathrm{a}-H), 4.32\left(1 \mathrm{H}, \mathrm{dd}, J_{1}=2.0 \mathrm{~Hz}, J_{2}=1.0 \mathrm{~Hz}, 6 \mathrm{a}-H\right)$, $4.43(1 \mathrm{H}, \mathrm{d}, J=1.0 \mathrm{~Hz}, 7-H), 5.72(1 \mathrm{H}, \mathrm{s}, 9-H), 6.57(1 \mathrm{H}, \mathrm{s}, 4-H)$, $6.75(1 \mathrm{H}, \mathrm{s}, 1-H) .{ }^{13} \mathrm{C}-\mathrm{NMR}\left(\mathrm{CDCl}_{3}\right): \delta 27.8,31.3,56.3,56.4,57.0$, 61.4, 62.8, 64.1, 76.4, 92.5, 107.3, 107.9, 112.9, 121.8, 127.5, 128.2, 136.1, 148.5, 150.2, 167.4, 193.6. HRMS (ESI-TOF) $m / z:[\mathrm{M}+\mathrm{Na}]^{+}$ Found 425.1212. Calcd. for $\mathrm{C}_{21} \mathrm{H}_{22} \mathrm{O}_{8} \mathrm{Na} 425.1226$. 


\section{Kinetic procedure}

BTNO radical was generated in acetonitrile in a thermostated quartz cuvette (optical path $=1 \mathrm{~cm}$ ) by adding a $0.5 \mathrm{mM}$ solution of CAN to a $0.5 \mathrm{mM}$ solution of HBT. A broad absorption band developed immediately $(8 \mathrm{~ms})$ in the $\lambda=350-600 \mathrm{~nm}$ region $\left(\lambda_{\max }\right.$ at $\left.474 \mathrm{~nm}, \varepsilon=1840 \mathrm{M}^{-1} \mathrm{~cm}^{-1}\right)$. The rate of decay was unaffected by the use of degassed acetonitrile. Rate constants of $\mathrm{H}$-abstraction from catechin derivatives $\mathbf{5}$ and $\mathbf{6}$ were determined at $25{ }^{\circ} \mathrm{C}$ in acetonitrile by following the decrease of the absorbance at $\lambda=474 \mathrm{~nm}$ of BTNO. The initial concentrations of the substrate were in the $5 \times 10^{-3}$ to $40 \times$ $10^{-3} \mathrm{M}$ range to enable a pseudo-first-order treatment of the kinetic data. A first order exponential was a good fit for plots of $\left(A_{\mathrm{t}}-A^{\circ}\right) v s$. time over more than three half-lives; the rate constants $\left(k_{0}\right)$ were obtained. From a plot of four to five $k_{0} v s$. [substrate $]_{0}$ data pairs, the second-order rate constant of $\mathrm{H}$ abstraction $\left(k_{\mathrm{H}}\right)$ was obtained.

\section{Cyclic voltammetry}

The electrochemical equipment consisted of a computercontrolled in-house potentiostat with a Vernier Software Multi Purpose Laboratory Interface (MPLI) program for Windows. The three electrodes consisted of a glassy-carbon disk (diameter of 1 $\mathrm{mm}$ ) working electrode, an $\mathrm{Ag} / \mathrm{AgCl} / \mathrm{KCl} 3 \mathrm{M}$ reference electrode $\left(E^{\circ} v s . \mathrm{NHE}=E^{\circ}(v s . \mathrm{Ag} / \mathrm{AgCl})+0.221\right)$, and a Pt auxiliary electrode $\left(1 \mathrm{~cm}^{2}\right)$. All scans were obtained at room temperature. The cyclic voltammetry scans of $2.0 \mathrm{mM}$ of compounds 5 or 6 in acetonitrile solution containing $0.1 \mathrm{M} \mathrm{Bu}_{4} \mathrm{NBF}_{4}$ as supporting electrolyte, were run at a rate of $0.5 \mathrm{~V} \mathrm{~s}^{-1}$.

\section{Computational methods}

All calculations were performed with software packages running on a PC equipped with Quad-Core AMD Opteron(tm) Processor 2376, 2.30-GHz (2 processors), 16 GB of RAM and OS 64-bit Windows 7 Ultimate. All optimizations of geometries of ground states, radicals, and transition states were performed by the computer program SPARTAN 08 (Wavefunction, Inc., Irvine, CA, USA). All details regarding the performed calculations are reported in ESI. $\dagger^{25}$

\section{References}

1 (a) S. Berthet, J. Thevenin, D. Baratiny, N. Demont-Caulet, I. Debeaujon, P. Bidzinski, J.-C. Leple, R. Huis, S. Hawkins, L.-D. Gomez, C. Lapiere and L. Jouanin, Adv. Bot. Res., 2012, 61, 145-172; (b) B. Gavnholt and K. Larsen, Physiol. Plant., 2002, 116, 273-280.

2 (a) N. Santhanam, J. M. Vivanco, S. R. Decker and K. F. Reardon, Trends Biotechnol., 2011, 29, 480-489, and references cited therein; (b) U. N. Dwivedi, P. Singh, V. P. Pandey and A. Kumar, J. Mol. Catal. B: Enzym., 2011, 68, 117-128; (c) P. Sharma, R. Goel and N. Capalash, World J. Microbiol. Biotechnol., 2007, 23, 823-832.

3 (a) J. Polak and A. Jarosz-Wilkolazka, Biotechnol. Prog., 2012, 28, 93-102, and references cited therein; (b) P. Baldrian, K. Murugesan and Y.-S. Chang, Microb. Biotechnol., 2012, 5,
318-332; (c) F. Xu, T. Damhus, S. Danielsen and L. H. Ostergaard, in Modern Biooxidation: Enzymes, Reactions and Applications, ed. R. D. Schmid and V. B.Urlacher, Wiley-VCH Verlag GmbH \& Co. KGaA, 2007, pp. 43-75, and references cited therein; (d) S. Witayakran and A. J. Ragauskas, Adv. Synth. Catal., 2009, 351, 1187-1209.

4 (a) M. Seki, J. Oikawa, T. Taguchi, T. Ohnuki, Y. Muramatsu, K. Sakamoto and S. Amachi, Environ. Sci. Technol., 2013, 47, 390-397; (b) D. Schlosser and C. Hofer, Appl. Environ. Microbiol., 2002, 68, 3514-3521; (c) J. Li-Cai, H. Pei-Zhi, J. Chang-Hua and D. Zi-Rong, Wuhan Univ. J. Nat. Sci., 2000, 5, 351-356; (d) C. Hofer and D. Schlosser, FEBS Lett., 1999, 451, 186-190.

5 (a) A. I. Cañas and S. Camarero, Biotechnol. Adv., 2010, 28, 694-705, and references cited therein; $(b)$ R. Bourbonnais and M. G. Paice, FEBS Lett., 1990, 267, 99-102; (c) H. P. Call and I. Mucke, J. Biotechnol., 1997, 53, 163-202.

6 (a) P. Astolfi, P. Brandi, C. Galli, P. Gentili, M. F. Gerini, L. Greci and O. Lanzalunga, New J. Chem., 2005, 29, 1-10, and references cited therein; (b) C. Galli and P. Gentili, $J$. Phys. Org. Chem., 2004, 17, 973-977, and references cited therein; (c) F. d'Acunzo and C. Galli, Eur. J. Biochem., 2003, 270, 3634-3640; (d) Y. Zhao and D. G. Truhlar, Theor. Chem. Acc., 2008, 120, 215-241.

7 (a) W. Y. Feng, Curr. Drug Metab., 2006, 7, 755-809; (b) N. Khan and H. Mukhtar, Life Sci., 2007, 519-533; (c) J. D. Lambert, S. Sang and C. S. Yang, Mol. Pharm., 2007, 4, 819-825.

8 (a) K. Fukuhara, I. Nakanishi, T. Shimada, K. Ohkubo, K. Miyazaki, W. Hakamata, S. Urano, T. Ozawa, H. Okuda, N. Miyata, N. Ikota and S. Fukuzumi, Chem. Res. Toxicol., 2003, 16, 81-86; (b) I. Nakanishi, K. Ohkubo, K. Miyazaki, W. Hakamata, S. Urano, T. Ozawa, H. Okuda, S. Fukuzumi, N. Ikota and K. Fukuhara, Chem. Res. Toxicol., 2004, 17, 26-31. 9 (a) V. Cheynier, C. Osse and J. Rigaud, J. Food Sci., 1988, 53, 1729-1731; (b) Y. Hirose, H. Yamaoka and M. Nakayama, J. Am. Oil Chem. Soc., 1991, 68, 131-132; (c) T. Tanaka, M. Takahashi, H. Hagino, S.-I. Nudejima, H. Usui, T. Fujii and M. Taniguchi, Chem. Eng. Sci., 2009, 65, 569-573; (d) D. Areskogh, J. Li, P. Nousiainen, G. Gellerstedt, J. Sipilae and G. Henriksson, Holzforschung, 2010, 64, 21-34; (e) S. Ghidouche, N.-E. Es-Safi and P.-H. Ducrot, Tetrahedron Lett., 2008, 49, 619-623, and references therein.

10 (a) M. Kurisawa, J. E. Chung, H. Uyama and S. Kobayashi, Macromol. Biosci., 2003, 3, 758-764; (b) H. Shibuya, A. Agusta, K. Ohashi, S. Maehara and P. Simanjuntak, Chem. Pharm. Bull., 2005, 53, 866-867; (c) A. Agusta, S. Maehara, K. Ohashi, P. Simanjuntak and H. Shibuya, Chem. Pharm. Bull., 2005, 53, 1565-1569.

11 R. Bernini, F. Crisante, P. Gentili, F. Morana, M. Pierini and M. Piras, J. Org. Chem., 2011, 76, 820-832.

12 (a) M. Barontini, R. Bernini, F. Crisante and G. Fabrizi, Tetrahedron, 2010, 66, 6047-6053; (b) R. Bernini, F. Crisante, G. Fabrizi and P. Gentili, Curr. Org. Chem., 2012, 16, 1051-1057; (c) R. Bernini, G. Fabrizi, L. Pouységu, D. Deffieux and S. Quideau, Curr. Org. Synth., 2012, 9, 650669; (d) R. Bernini, F. Crisante, M. Barontini, D. Tofani, 
V. Balducci and A. Gambacorta, J. Agric. Food Chem., 2012, 60, 7408-7416.

13 K. Fukuhara, I. Nakanishi, H. Kansui, E. Sugiyama, M. Kimura, T. Shimada, S. Urano, K. Yamaguchi and N. Miyata, J. Am. Chem. Soc., 2002, 124, 5952.

14 (a) Y. Y. Wan, R. Lu, L. Xiao, Y.-M. Du, T. Miyakoshi, C.-L. Chen, C. J. Knill and J. F. Kennedy, Int. J. Biol. Macromol., 2010, 47, 488-495; (b) J. Rodakiewicz-Nowak and A. Jarosz-Wilkolazka, J. Mol. Catal. B: Enzym., 2007, 44, 53-59, and references cited therein; (c) F. d'Acunzo, A. M. Barreca and C. Galli, J. Mol. Catal. B: Enzym., 2004, 31, 25-30, and references cited therein.

15 (a) C. Navarra, P. Gavezzotti, D. Monti, W. Panzeri and S. Riva, J. Mol. Catal. B: Enzym., 2012, 84, 115-120, and references cited therein; (b) O. E. Adelakun, T. I. Kudanga, I. R. Green, M. Le Roes-Hill and S. G. Burton, Process Biochem., 2012, 47, 1926-1932, and references cited therein; (c) C. Navarra, C. Goodwin, S. Burton, B. Danieli and S. Riva, J. Mol. Catal. B: Enzym., 2010, 65, 52-57, and references cited therein.

16 (a) N. L. Klyachko, N. G. Bogdanove, A. V. Levashov and K. Martinek, Collect. Czech. Chem. Commun., 1992, 57, 625640; (b) A. V. Pshezhetskii, N. L. Klyachko, A. V. Levashov and K. Martinek, Biocatalysis, 1990, 4, 185-198.

17 (a) J. Michizoe, H. Ichinose, N. Kamiya, T. Maruyama and M. Goto, J. Biosci. Bioeng., 2005, 99, 642-647; (b)
S. Ozakazi, J. Michizoe, M. Goto, S. Furusaki, H. Wariishi and H. Tanaka, Enzyme Microb. Technol., 2002, 31, 227232; (c) J. Michizoe, M. Goto and S. Furusaki, J. Biosci. Bioeng., 2001, 92, 67-71.

18 F. Xu, A. E. Palmer, D. S. Yaver, R. M. Berka, G. A. Gambetta, S. H. Brown and E. I. Solomon, J. Biol. Chem., 1999, 274, 12372-12375.

19 P. Brandi, C. Galli and P. Gentili, J. Org. Chem., 2005, 70, 9521-9528.

20 (a) D. Griller, J. A. Howard, P. R. Marriott and J. C. Scaiano, J. Am. Chem. Soc., 1981, 103, 619-624; (b) A. L. J. Beckwith and C. J. Easton, J. Am. Chem. Soc., 1981, 103, 615-619; (c) V. Malatesta and J. C. Scaiano, J. Org. Chem., 1982, 47, 1455-1459.

21 CRC Handbook of Chemistry and Physics, ed. D. R. Lide, CRC Press Boca Raton, FL., 74 edn, 1993.

22 F. Xu, Biochemistry, 1996, 35, 7608-7614.

23 B. S. Wolfenden and R. L. Willson, J. Chem. Soc., Perkin Trans. 2, 1982, 805-812.

24 (a) H. Liu, Y. Yamazaki, T. Sasaki, M. Uchida, H. Tanaka and S. Oka, Phytochemistry, 1999, 51, 297-308; (b) K. Hori, T. Satake, Y. Saiki, T. Murakami and C.-M. Chen, Chem. Pharm. Bull., 1988, 36, 4301-4306.

25 (a) O. Tishchenko and D. G. Truhlar, J. Phys. Chem. Lett., 2012, 3, 2834-2839; (b) I. Hermans, P. Jacobs and J. Peeters, Phys. Chem. Chem. Phys., 2008, 10, 1125-1132. 